\title{
Tingkat Kemiskinan Di Pulau Papua Tahun 2011-2017
}

\author{
Yuliana Harianja ${ }^{1}$, Sahara ${ }^{2}$, Muhammad Findi ${ }^{2}$ \\ ${ }^{1}$ Badan Pusat Statistik Kabupaten Biak Numfor, Provinsi Papua \\ ${ }^{2}$ Departemen Ilmu Ekonomi \\ Fakultas Ekonomi dan Manajemen, Institut Pertanian Bogor \\ *Korespondensi: y.harianja70@gmail.com
}

[diterima: Agustus 2018-revisi: September 2018-diterbitkan daring: Desember 2018]

\begin{abstract}
ABSTRAK
Pengentasan kemiskinan merupakan salah satu tujuan pembangunan ekonomi. Selama tahun 2011 hingga 2017, Provinsi Papua dan Papua Barat yang terletak di Pulau Papua memiliki tingkat kemiskinan tertinggi pertama dan kedua di Indonesia. Studi ini menganalisis faktor-faktor yang memengaruhi kemiskinan di Pulau Papua selama tahun 2011 hingga 2017 menggunakan regresi data panel. Hasil yang diperoleh menunjukkan bahwa variabel-variabel PDRB (Produk Domestik Regional Bruto) per kapita sektor pertambangan dan penggalian, PDRB per kapita sektor konstruksi, dan pendidikan berpengaruh signifikan terhadap penurunan tingkat kemiskinan
\end{abstract}

Kata kunci: Kemiskinan, Pembangunan Ekonomi, Regresi Data Panel

\begin{abstract}
Poverty alleviation is one of the goals of economic development. During 2011 to 2017, both Papua and West Papua Provinces located in Papua Island are two provinces with the highest poverty rate in Indonesia. This study analyzed the factors that affect poverty rate in Papua Island during 2011 to 2017 using the panel regression model. The results showed that GRDP(Gross Regional Domestic Product) per capita of the mining sector, GRDP per capita of the construction sector, and education had a significant effect on reducing poverty
\end{abstract}

Keywords: Economic Development, Panel Data Regression, Poverty

JEL Classification: O1, C23, 132 


\section{PENDAHULUAN}

Pada hakikatnya, pembangunan ekonomi adalah serangkaian usaha dan kebijakan yang bertujuan untuk meningkatkan taraf hidup masyarakat secara keseluruhan. Tujuan utama pembangunan ekonomi tidak sekedar mengejar tingkat pertumbuhan ekonomi yang tinggi, tetapi juga pengurangan tingkat kemiskinan, penanggulangan ketidakmerataan pendapatan, dan perluasan lapangan pekerjaan (Todaro dan Smith 2006).

Pada bulan September 2015, Perserikatan Bangsa Bangsa (PBB) meluncurkan Sustainable Development Goals (SDGs) atau Tujuan Pembangunan Berkelanjutan yang merupakan rencana aksi global sepanjang tahun 2016 hingga 2030 yang berisi 17 tujuan dan 169 target. Seluruh tujuan dan target tersebut mencakup tiga dimensi pembangunan berkelanjutan, yaitu ekonomi, sosial, dan lingkungan. Tujuan pertama dalam SDGs adalah mengakhiri kemiskinan dalam segala bentuk dimanapun. Perserikatan Bangsa Bangsa (PBB) menempatkan "tanpa kemiskinan" sebagai tujuan pertama dari SDGs karena PBB memandang bahwa kemiskinan merupakan masalah serius yang dihadapi oleh banyak negara di dunia, terutama negara berkembang.

Sejalan dengan tujuan pertama SDGs tersebut, pemerintah Indonesia telah mengupayakan berbagai strategi untuk pengentasan kemiskinan, seperti perlindungan sosial yang komprehensif, penyediaan dan peningkatan akses layanan dasar, dan memperluas mata pencaharian yang layak serta berkelanjutan. Berbagai usaha pemerintah dalam mengentaskan kemiskinan di Indonesia beberapa tahun belakangan ini telah berhasil menurunkan angka kemiskinan nasional. Badan Pusat Statistik (BPS) mencatat bahwa tingkat kemiskinan di Indonesia pada tahun 2011 adalah senilai 12.49 persen (30.02 juta orang) dan nilai ini turun menjadi 10.64 persen (27.77 juta orang) pada tahun 2017 (BPS 2018c).

Angka kemiskinan nasional tidak mencerminkan realita di setiap provinsi. Selama tahun 2011 hingga 2017, Provinsi Papua dan Papua Barat yang terletak di Pulau Papua memiliki tingkat kemiskinan tertinggi pertama dan kedua di antara semua provinsi di Indonesia.
Pada tahun 2017, tingkat kemiskinan Provinsi Papua dan Provinsi Papua Barat masing-masing sebesar 27.62 persen (897.69 ribu orang) dan 25.10 persen (228.38 ribu orang). Tingkat kemiskinan kedua provinsi tersebut jauh di atas tingkat kemiskinan nasional di tahun yang sama (BPS 2018a, 2018b, 2018c).

Sejak tahun 2001, pemerintah Indonesia memberikan otonomi khusus bagi Provinsi Papua melalui Undang-Undang No. 21 Tahun 2001 yang disesuaikan dengan Undang-Undang No. 35 Tahun 2008 tentang Otonomi Khusus (Otsus) bagi Provinsi Papua dan Papua Barat. Sehubungan dengan pemberlakuan otonomi khusus tersebut, pemerintah Provinsi Papua menerima dana otsus sejak tahun 2002 dan dana tambahan infrastruktur (DTI) sejak tahun 2006, sedangkan pemerintah Provinsi Papua Barat menerima dana otsus maupun DTI sejak tahun 2009. Total dana otsus dan DTI bagi Provinsi Papua maupun Papua Barat sejak awal diberikan hingga tahun 2017 adalah sebesar 89.86 triliun rupiah (KEMENKEU 2019). Pemanfaatan dana otsus terutama ditujukan untuk pembiayaan pendidikan dan kesehatan, sedangkan DTI untuk pembiayaan pembangunan infrastruktur.

Maksud pemberian otonomi khusus bagi Provinsi Papua dan Papua Barat dalam bidang pembangunan ekonomi adalah tercapainya percepatan pembangunan guna peningkatan kesejahteraan masyarakat Papua. Kehadiran otsus diharapkan dapat meningkatkan kualitas pendidikan serta kualitas kesehatan masyarakat Papua sehingga masyarakat Papua dapat hidup semakin sejahtera. Adanya dana otsus untuk pembangunan infrastruktur di Pulau Papua diharapkan dapat membuka akses wilayahwilayah yang sebelumnya sangat terpencil atau terisolasi sehingga perekonomian wilayah tersebut semakin baik.

Pulau Papua yang hanya terdiri atas dua provinsi, Papua dan Papua Barat, memiliki sumberdaya alam yang melimpah. Keberadaan PT. Freeport Indonesia sebagai perusahaan tambang tembaga, emas, dan perak yang besar membuktikan kekayaan alam Papua. Berdasarkan nilai Produk Domestik Regional Bruto Atas Dasar Harga Konstan (PDRB ADHK) tahun 2011 hingga 2017, perekonomian di Papua sangat didominasi oleh sektor pertambangan dan 
penggalian (BPS 2018d, 2018e). Keadaan sumberdaya alam yang kaya diharapkan dapat membawa kesejahteraan bagi masyarakat Pulau Papua.

Berdasarkan uraian di atas, maka tujuan penelitian adalah menganalisis faktor-faktor yang memengaruhi tingkat kemiskinan di Pulau Papua tahun 2011 hingga 2017.

\section{TINJAUAN PUSTAKA}

Berdasarkan standar penilaiannya, kemiskinan dibedakan atas kemiskinan relatif dan absolut. Kemiskinan relatif adalah kemiskinan yang diukur berdasarkan perbandingan antarkelompok dalam masyarakat, dimana suatu kelompok dianggap relatif lebih miskin dibanding kelompok lainnya. Sedangkan kemiskinan absolut yaitu ketidakmampuan mendapat sumber daya yang cukup untuk memenuhi kebutuhan dasar. Penduduk yang digolongkan dalam kemiskinan absolut adalah mereka yang hidup di bawah garis kemiskinan (Todaro dan Smith 2006).

Pengertian kemiskinan menurut Badan Pusat Statistik (BPS) diartikan sebagai ketidakmampuan dari sisi ekonomi untuk memenuhi kebutuhan dasar makanan dan bukan makanan yang diukur dari sisi pengeluaran. Penduduk yang memiliki rata-rata pengeluaran per kapita per bulan di bawah Garis Kemiskinan (GK) dikategorikan sebagai penduduk miskin. GK merupakan penjumlahan dari Garis Kemiskinan Makanan (GKM) dan Garis Kemiskinan Non Makanan (GKNM). GKM merupakan nilai pengeluaran kebutuhan minuman makanan seseorang yang disetarakan 2 100 kilokalori per kapita per hari, sedangkan GKNM merupakan nilai kebutuhan minimum untuk perumahan, sandang, pendidikan, dan kesehatan. Persentase penduduk miskin yaitu proporsi dari penduduk yang hidup di bawah garis kemiskinan terhadap total penduduk (BPS 2017). Penelitian ini menggunakan definisi kemiskinan menurut BPS.

Pada tahun 2017, nilai GK di Provinsi Papua Barat adalah 499778 rupiah dan Provinsi Papua senilai 457541 rupiah. Nilai GK di tingkat kabupaten/kota berbeda dengan GK di tingkat Provinsi. Setiap kabupaten/kota memiliki nilai GK masing-masing di mana pada tahun 2017,
Kota Jayapura memiliki GK tertinggi sebesar 849 496 rupiah dan Kabupaten Tolikara memiliki GK terendah sebesar 252132 rupiah (BPS 2018a, 2018b).

Menurut Murohman et al. (2016), pemenuhan kebutuhan dasar yang rendah mencerminkan rendahnya pendapatan. Oleh karena itu, perlu adanya upaya peningkatan pendapatan agar kesempatan seseorang terlepas dari kemiskinan semakin tinggi. Indikator yang dapat digunakan sebagai pendekatan pendapatan adalah Produk Domestik Regional Bruto (PDRB).

PDRB adalah jumlah nilai tambah yang dihasilkan oleh seluruh unit usaha dalam suatu daerah tertentu, atau jumlah nilai barang dan jasa akhir yang dihasilkan oleh seluruh unit ekonomi dalam jangka waktu tertentu. PDRB per kapita menunjukkan nilai PDRB per satu orang penduduk (BPS 2018d). BPS menyajikan data PDRB atas dasar harga berlaku (ADHB) dan atas dasar harga konstan (ADHK). PDRB ADHB atau PDRB nominal dihitung berdasarkan harga tahun berjalan, sedangkan PDRB ADHK atau PDRB riil dihitung berdasarkan harga tahun tertentu sebagai upaya penghilangan faktor harga. Penelitian yang dilakukan oleh Ratri (2011) menunjukkan bahwa peningkatan PDRB per kapita berpengaruh terhadap penurunan tingkat kemiskinan.

Pada tahun 2016, Quy melakukan penelitian di Vietnam mengenai pengaruh investasi terhadap kemiskinan dan memeroleh hasil yang menunjukkan bahwa peningkatan investasi berdampak pada penurunan angka kemiskinan. Indikator yang menyatakan nilai investasi fisik di suatu wilayah adalah Pembentukan Modal Tetap Bruto (PMTB). PMTB mencakup pembuatan dan pembelian barang-barang modal baru dari dalam daerah dan barang modal bekas atau baru dari luar daerah (BPS 2018f, 2018g). Data PMTB yang disajikan oleh BPS terbagi atas data bangunan dan non bangunan. Yang termasuk non bangunan antara lain mesin dan perlengkapan, kendaaraan, cultivated biological resources (CBR), dan produk kekayaan intelektual.

Kemiskinan tercermin dalam pendapatan per kapita yang rendah dan juga kualitas kesehatan dan pendidikan yang rendah (Jhingan 2016). Usman (2006) dalam studinya menyatakan bahwa sektor pendidikan dan kesehatan harus 
mendapatkan perhatian pemerintah daerah karena pembangunan di sektor tersebut dapat membantu program penanggulangan kemiskinan. Bintang dan Woyanti (2018) menunjukkan bahwa Ratarata Lama Sekolah (RLS) sebagai pendekatan pengukuran bidang pendidikan dan Angka Harapan Hidup (AHH) sebagai pendekatan pengukuran bidang kesehatan berkonstribusi terhadap penurunan kemiskinan. Rata-rata Lama Sekolah adalah rata-rata jumlah tahun yang digunakan penduduk usia 25 tahun ke atas dalam menjalani pendidikan formal. Angka Harapan Hidup adalah rata-rata perkiraan banyaknya tahun yang ditempuh seseorang selama hidup.

\section{METODE Jenis dan Sumber Data}

Penelitian ini menggunakan data sekunder yang berasal dari Badan Pusat Statistik (BPS). Jenis datanya adalah data panel yang mencakup data cross section 40 kabupaten/kota di Pulau Papua dan data time series periode tahun 2011 hingga 2017. Adapun data yang digunakan adalah persentase penduduk miskin; PDRB ADHK per kapita sektor pertanian, kehutanan, dan perikanan; PDRB ADHK per kapita sektor pertambangan dan penggalian; PDRB ADHK per kapita sektor konstruksi; PDRB ADHK per kapita selain dari sektor pertanian, kehutanan, dan perikanan, sektor pertambangan dan penggalian, serta sektor konstruksi; Pembentukan Modal Tetap Bruto; Rata-rata Lama Sekolah; serta Angka Harapan Hidup.

\section{Metode Analisis dan Pengolahan Data}

Metode analisis yang digunakan dalam penelitian ini adalah analisis kuantitatif dengan menggunakan regresi data panel. Pada data panel, setiap unit cross section diobservasi secara berulang-ulang selama beberapa waktu. Jika terdapat individu $i$ (dimana $i=1,2,3, \ldots, N$ ) dalam periode pengamatan selama waktu $t$ (dimana $t=1,2,3, \ldots, T)$, maka dengan data panel akan terdapat observasi sebanyak $N T$.

Model regresi data panel secara umum dapat dinyatakan dalam persamaan berikut (Baltagi 2005).

$$
y_{i t}=\beta_{0}+\sum_{k=1}^{p} \beta_{k} x_{k i t}+\varepsilon_{i t}
$$

Keterangan :

$i \quad: \quad$ Unit cross section, $i=1,2, \ldots, N$

$t \quad$ : Periode, $t=1,2, \ldots, T$

$Y_{i t} \quad$ : Nilai variabel terikat dari unit ke- $i$ pada periode ke- $t$

$X_{k i t}$ : Nilai variabel bebas ke- $k$ dari unit ke- $i$ pada periode ke- $t$

$\beta_{0}:$ Intercept/konstanta regresi

$\beta_{k}:$ Slope/koefisien dugaan parameter regresi untuk variabel bebas ke- $k$

$\varepsilon_{i t} \quad:$ Residual unit ke- $i$ periode ke- $t$

Terdapat 3 pendekatan dalam mengestimasi model regresi data panel, yakni common effect model (CEM), fixed effect model (FEM), dan random effect model (REM). CEM adalah model yang paling sederhana karena tidak memerhatikan pengaruh lokasi dan waktu. Model tersebut dinamakan juga pooled least square. Model CEM mengasumsikan bahwa nilai intercept dan slope variabel bebas untuk semua unit cross section dan time series adalah sama. Sementara model FEM mengasumsikan nilai intercept berbeda-beda untuk setiap unit cross section, tetapi slope variabel bebas bernilai tetap. Pada model REM diasumsikan bahwa perbedaan nilai intercept merupakan variabel acak.

Pemilihan model yang paling tepat dalam analisis data panel dilakukan melalui beberapa uji. Uji-uji tersebut adalah uji Lagrange Multiplier, uji Chow, dan uji Hausman. Uji Lagrange Multiplier dilakukan untuk memeriksa mengenai keberadaan efek individu atau efek waktu. Hipotesis nol pada uji Lagrange Multiplier adalah tidak adanya efek individu atau efek waktu dalam model sehingga yang dipilih adalah CEM. Sebaliknya hipotesis alternatifnya adalah adanya efek individu atau efek waktu sehingga yang dipilih adalah REM. Uji Chow dilakukan untuk menguji apakah ada efek individu atau tidak. Jika tidak ada efek individu (hipotesis nol), model terbaik yang dipilih adalah CEM dan jika ada efek individu (hipotesis alternatif), model terbaiknya adalah FEM. Selanjutnya untuk memilih apakah model REM atau FEM yang terbaik, dilakukan uji Hausman, dimana hipotesis nol menyatakan ada korelasi antara efek individu dengan variabel bebas (REM) dan hipotesis alternatif menyatakan tidak 
ada korelasi antara efek individu dengan variabel bebas (FEM).

Model yang digunakan dalam penelitian ini mengacu pada penelitian Ratri (2011), Quy (2016), serta Bintang dan Woyanti (2018). Adapun model penelitian tersebut dinyatakan sebagai berikut.

$$
\begin{aligned}
& Y_{i t}=\beta_{0}+\beta_{1} X_{1 i t}+\beta_{2} X_{2 i t}+\beta_{3} X_{3 i t}+\beta_{4} X_{4 i t} \\
& \quad+\beta_{5} X_{5 i t}+\beta_{6} X_{6 i t}+\beta_{7} X_{7 i t}+\varepsilon_{i t}
\end{aligned}
$$

Keterangan :

$i \quad:$ Kabupaten/kota, $i=1,2, \ldots, 40$

$t \quad:$ Tahun, $t=2011,2012, \ldots, 2017$

$Y_{i t}$ : Tingkat kemiskinan atau persentase penduduk miskin di kabupaten/kota $i$ tahun $t$ (persen)

$X_{1 i t}$ : Logaritma natural dari PDRB per kapita sektor pertanian, kehutanan, dan perikanan di kabupaten/kota $i$ tahun $t(-)$

$X_{2 i t}$ : Logaritma natural dari PDRB per kapita sektor pertambangan dan penggalian di kabupaten/kota $i$ tahun $t(-)$

$X_{3 i t}$ : Logaritma natural dari PDRB per kapita sektor konstruksi di kabupaten/kota $i$ tahun $t(-)$

$X_{4 i t}$ : Logaritma natural dari PDRB per kapita selain sektor pertanian, kehutanan, dan perikanan; sektor pertambangan dan penggalian; serta sektor konstruksi di kabupaten/kota $i$ tahun $t(-)$

$X_{5 i t}$ : Logaritma natural dari Pembentukan Modal Tetap Bruto (PMTB) di kabupaten/kota $i$ tahun $t(-)$

$X_{6 i t}$ : Rata-rata Lama Sekolah (RLS) di kabupaten/kota $i$ tahun $t$ (tahun)

$X_{7 i t}$ : Angka Harapan Hidup (AHH) di kabupaten/kota $i$ tahun $t$ (tahun)

$\beta_{0} \quad$ : Konstanta regresi

$\beta_{k}$ : Koefisien dugaan parameter regresi untuk variabel bebas ke- $k, k=1,2,3, \ldots, 7$

$\varepsilon_{i t}$ : Residual regresi pada kabupaten/kota $i$ tahun $t$

\section{HASIL DAN PEMBAHASAN Gambaran Umum}

Pulau Papua terdiri dari dua provinsi, yakni Papua dan Papua Barat, dengan jumlah kabupaten sebanyak 40 dan kotamadya sebanyak 2. Penelitian ini hanya menganalisis kemiskinan di Pulau Papua menggunakan data panel dari 38 kabupaten dan 2 kotamadya untuk periode tahun 2011 hingga 2017. Terdapat dua kabupaten, yaitu Pegunungan Arfak dan Manokwari Selatan, yang tidak disertakan dalam penelitian ini karena kedua kabupaten tersebut belum mekar pada tahun 2011.

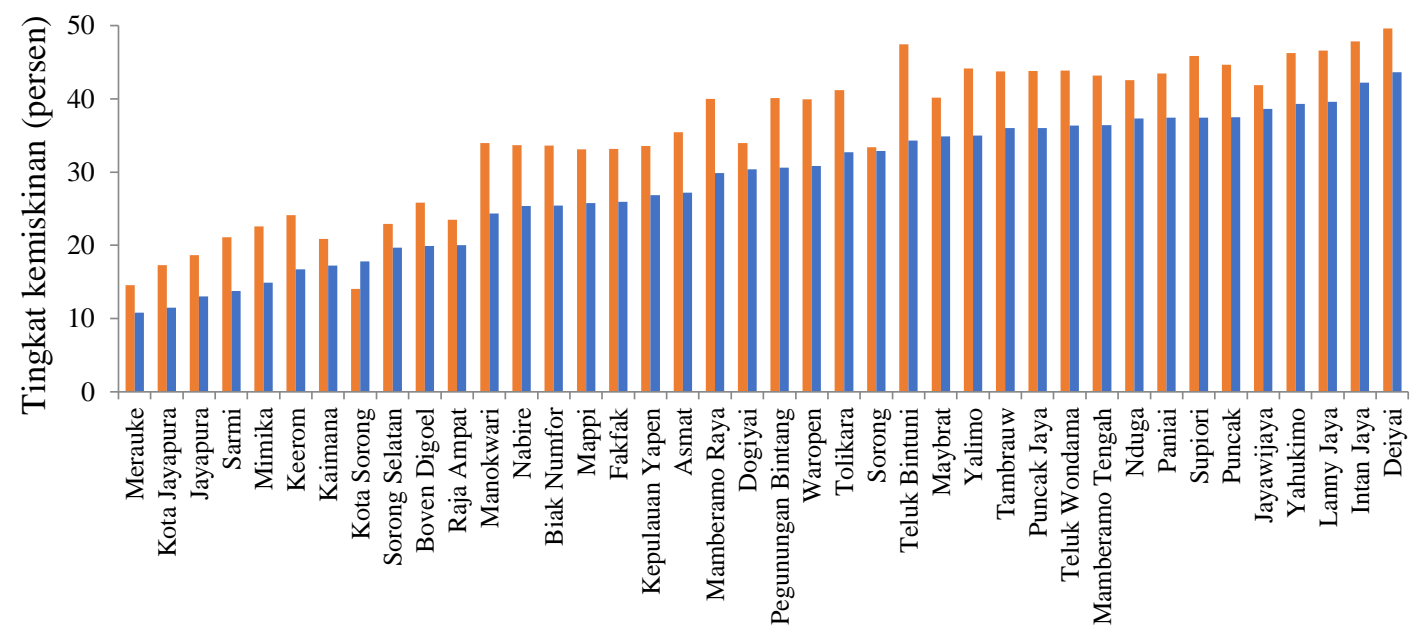

Kabupaten/Kota

—2011 $\quad 2017$

Sumber : BPS (2018a, 2018b), diolah

Gambar 1. Tingkat kemiskinan kabupaten/kota di Pulau Papua, 2011 dan 2017 
Gambar 1 menunjukkan tingkat kemiskinan kabupaten/kota di Pulau Papua tahun 2011 dan 2017. Secara umum terjadi penurunan tingkat kemiskinan kabupaten/kota di Pulau Papua dari tahun 2011 ke 2017. Tingkat kemiskinan terendah di tahun 2011 dimiliki Kota Sorong dengan nilai 14.04 persen dan tertinggi dimiliki Kab. Deiyai dengan nilai 49.58 persen. Pada tahun 2017, tingkat kemiskinan Kab. Merauke berada di posisi terendah dengan nilai 10.81 persen dan Kab. Deiyai tetap di posisi tertinggi dengan nilai 43.63 persen.

Hampir seluruh kabupaten/kota se-Pulau Papua memiliki tingkat kemiskinan yang selalu di atas tingkat kemiskinan nasional. Pada tahun
2011 hingga 2013, serta tahun 2016 dan 2017, seluruh kabupaten/kota di Papua memiliki tingkat kemiskinan di atas level nasional. Pada tahun 2014 dan 2015, hanya Kabupaten Merauke yang memiliki tingkat kemiskinan di bawah angka nasional. Tingkat kemiskinan Kabupaten Merauke adalah sebesar 10.20 persen di tahun 2014 dan 11.10 persen di tahun 2015, sedangkan tingkat kemiskinan nasional sebesar 11.25 persen di tahun 2014 dan 11.22 persen di tahun 2015 (BPS 2018a, 2018b, 2018c). Meskipun tingkat kemiskinan di Pulau Papua antara tahun 2011 dan 2017 mengalami penurunan, tingkat kemiskinan setiap kabupaten/kota secara umum berada jauh di atas tingkat kemiskinan nasional.

Tabel 1. Distribusi PDRB ADHK menurut Lapangan Usaha di Pulau Papua, 2011-2017 (persen)

\begin{tabular}{lrrrrrrr}
\hline Lapangan Usaha & 2011 & 2012 & 2013 & 2014 & 2015 & 2016 & 2017 \\
\hline A. Pertanian, Kehutanan, dan Perikanan & 11.22 & 11.60 & 11.38 & 11.52 & 11.32 & 10.69 & 10.67 \\
B. Pertambangan dan Penggalian & 41.13 & 37.81 & 37.57 & 35.30 & 35.07 & 36.09 & 35.60 \\
C. Industri Pengolahan & 10.95 & 11.00 & 10.94 & 10.98 & 10.56 & 10.13 & 10.01 \\
D. Pengadaan Listrik dan Gas & 0.03 & 0.03 & 0.03 & 0.04 & 0.03 & 0.03 & 0.03 \\
E. Pengadaan Air, Pengelolaan Sampah, & 0.07 & 0.07 & 0.07 & 0.07 & 0.07 & 0.07 & 0.07 \\
$\quad$ Limbah dan Daur Ulang & & & & & & & \\
F. Konstruksi & 8.71 & 9.68 & 10.10 & 10.64 & 11.04 & 11.17 & 11.38 \\
G. Perdagangan Besar dan Eceran; Reparasi & 6.62 & 7.04 & 7.09 & 7.31 & 7.41 & 7.38 & 7.54 \\
$\quad$ & & & & & & & \\
H. Trabil dan Sepeda Motor & 3.12 & 3.34 & 3.37 & 3.59 & 3.69 & 3.70 & 3.77 \\
I. Penyediaan Akomodasi dan Makan & 0.55 & 0.58 & 0.59 & 0.63 & 0.63 & 0.63 & 0.64 \\
$\quad$ Minum & & & & & & & \\
J. Informasi dan Komunikasi & 2.70 & 2.93 & 3.04 & 3.14 & 3.11 & 3.01 & 3.09 \\
K. Jasa Keuangan dan Asuransi & 1.23 & 1.32 & 1.42 & 1.47 & 1.45 & 1.41 & 1.39 \\
L. Real Estate & 1.76 & 1.90 & 1.94 & 2.02 & 2.01 & 2.00 & 2.03 \\
M,N. Jasa Perusahaan & 0.80 & 0.84 & 0.82 & 0.86 & 0.84 & 0.83 & 0.84 \\
O. Administrasi Pemerintahan, Pertahanan & 7.29 & 7.80 & 7.55 & 8.18 & 8.47 & 8.59 & 8.61 \\
$\quad$ dan Jaminan Sosial Wajib & & & & & & & \\
P. Jasa Pendidikan & 1.93 & 2.04 & 2.07 & 2.16 & 2.17 & 2.16 & 2.20 \\
Q. Jasa Kesehatan dan Kegiatan Sosial & 1.16 & 1.23 & 1.22 & 1.28 & 1.30 & 1.30 & 1.31 \\
R,S,T,U. Jasa lainnya & 0.73 & 0.77 & 0.79 & 0.82 & 0.82 & 0.81 & 0.82
\end{tabular}

Sumber : BPS (2018d, 2018e), diolah

Berdasarkan nilai proporsi PDRB ADHK menurut Lapangan Usaha di Pulau Papua (Tabel 1), lapangan usaha yang memiliki nilai proporsi terbesar sepanjang tahun 2011 hingga 2017 adalah sektor pertambangan dan penggalian. Nilai proporsi yang sangat besar ini tentu saja terjadi karena adanya kegiatan pertambangan oleh PT. Freeport Indonesia yang terletak di Kabupaten Mimika, Provinsi Papua. Tidak hanya di Provinsi Papua, sektor pertambangan dan penggalian di Provinsi Papua Barat juga merupakan salah satu sektor ekonomi yang sangat dominan dalam perekonomian Papua Barat.

Pada tahun 2011, lapangan usaha yang berada pada urutan kedua tertinggi adalah pertanian, kehutanan, dan perikanan, kemudian disusul lapangan usaha industri pengolahan. Ketiga lapangan usaha yang berada pada posisi 
pertama hingga ketiga tersebut memiliki pola urutan proporsi yang sama dalam struktur perekonomian Pulau Papua sampai dengan tahun 2014. Sejak tahun 2015, nilai share industri pengolahan mengalami penurunan, sedangkan sektor konstruksi mulai mengalami peningkatan sampai melambung melebihi sektor industri pengolahan. Selanjutnya pada tahun sejak 2016 sektor konstruksi melampaui sektor pertanian, kehutanan, dan perikanan sehingga pada tahun 2017, lapangan usaha yang memiliki proporsi terbesar pertama hingga ketiga berturut-turut adalah sektor pertambangan dan penggalian; sektor konstruksi; serta sektor pertanian, kehutanan, dan perikanan. Peningkatan sektor konstruksi terjadi karena pembangunan infrastruktur di Papua meningkat tajam sejak tahun 2015 (BPS 2018d, 2018e).

Data mengenai investasi fisik atau data PMTB (Pembentukan Modal Tetap Bruto) yang dipublikasikan oleh BPS menunjukkan bahwa sepanjang tahun 2011 hingga 2017 nilai investasi fisik di Pulau Papua terus mengalami peningkatan. Nilai PMTB dalam PDRB menurut Pengeluaran di Pulau Papua tahun 2011 adalah sebesar 34.42 triliun rupiah dan terus mengalami peningkatan hingga mencapai 50.87 triliun rupiah di tahun 2017 (BPS 2018f). Berdasarkan data BPS, investasi dalam bentuk bangunan di Pulau Papua sepanjang tahun 2011 hingga 2017 bernilai rata-rata dua kali lipat dibanding nilai investasi dalam bentuk non-bangunan.

Selama kurun waktu tahun 2011 hingga 2017 terjadi perbaikan kualitas pendidikan di Provinsi Papua dan Papua Barat. Kualitas pendidikan Provinsi Papua tercermin dari data Rata-rata Lama Sekolah (RLS) yang mengalami kenaikan menjadi 6.27 pada tahun 2017 yang sebelumnya sebesar 5.6 pada tahun 2011. Angka RLS sebesar 6.27 memiliki arti bahwa penduduk Provinsi Papua yang berusia 15 tahun ke atas secara rata- rata telah menempuh pendidikan selama 6.27 tahun atau hingga kelas VII setara SMP. Baik pada tahun 2011 maupun 2017, angka RLS Provinsi Papua adalah yang terendah di antara provinsi lainnnya di Indonesia. Kualitas pendidikan di Provinsi Papua Barat relatif lebih baik dibanding Provinsi Papua. Pada tahun 2011, penduduk Provinsi Papua Barat yang berusia 15 tahun ke atas secara rata-rata telah menempuh pendidikan selama 6.82 tahun atau hingga kelas VII setara SMP. Kualitas pendidikan Provinsi Papua Barat semakin baik pada tahun 2017 dimana rata-rata lama sekolah senilai 7.15 atau setara SMP kelas VIII.

Angka Harapan Hidup (AHH) di Provinsi Papua dan Papua Barat mengalami peningkatan dari tahun ke tahun. AHH Provinsi Papua pada tahun 2011 sebesar 64.46 meningkat menjadi 65.14 di tahun 2017, sedangkan AHH Provinsi Papua Barat yang bernilai 64.75 pada tahun 2011, juga mengalami peningkatan menjadi 65.32 di tahun 2017. Peningkatan nilai AHH menandakan bahwa terjadi perbaikan kualitas kesehatan masyarakat karena adanya perbaikan dalam sistem dan pelayanan kesehatan. Kendati AHH mengalami peningkatan, AHH di Provinsi Papua dan Papua Barat masih relatif rendah dibanding provinsi lain di Indonesia.

\section{Faktor-faktor yang Memengaruhi Tingkat Kemiskinan}

Berdasarkan hasil analisis menggunakan regresi panel, dari ketiga pendekatan model panel: common effect model (CEM), fixed effect model (FEM), dan random effect model (REM), terpilih model panel terbaik yaitu fixed effect model (FEM). Terpilihnya fixed effect model (FEM) tersebut dilakukan melalui serangkaian pengujian yang hasilnya ditunjukkan dalam Tabel 2.

Tabel 2. Hasil uji pemilihan model panel terbaik

\begin{tabular}{cccc}
\hline Jenis Uji & Kriteria uji & Hasil $p$-value & Model terbaik \\
\hline Lagrange Multiplier & $\mathrm{H}_{0}:$ CEM dan $\mathrm{H}_{1}:$ REM & $2.2 \times 10^{-16}$ & REM \\
Chow & $\mathrm{H}_{0}:$ CEM dan $\mathrm{H}_{1}:$ FEM & $2.2 \times 10^{-16}$ & FEM \\
Hausman & $\mathrm{H}_{0}:$ REM dan $\mathrm{H}_{1}:$ FEM & $2.2 \times 10^{-16}$ & FEM \\
\hline
\end{tabular}


Uji Lagrange Multiplier menghasilkan $p$-value yang nilainya kurang dari taraf sifgnifikan 0.1 persen, sehingga hipotesis nol ditolak, artinya model REM lebih tepat daripada CEM. Selanjutnya, $p$-value yang dihasilkan dalam uji Chow bernilai kurang dari taraf sifgnifikan 0.1 persen sehingga hipotesis nol ditolak dimana hal ini berarti lebih tepat untuk memilih model FEM dan bukan CEM. Dari kedua uji Lagrange Multiplier dan Chow, terdapat dua pilihan model yang baik, REM atau FEM. Untuk itu perlu dilakukan uji lanjutan untuk memilih satu model terbaik dari kedua model tersebut, yaitu uji Hausman. Hasil p-value pada uji Hausman yang bernilai kurang dari taraf signifikan 0.1 persen mengakibatkan hipotesis nol ditolak. Penolakan hipotesis nol pada uji Hausman menyimpulkan bahwa model yang tepat adalah model FEM. Dengan demikian dari ketiga model panel CEM, REM, dan FEM, model yang tepat untuk menganalisis faktor-faktor yang memengaruhi tingkat kemiskinan di Pulau Papua dalam penelitian ini adalah FEM.

Fixed effect model adalah model yang mempertimbangkan adanya perbedaan karakteristik kemiskinan setiap kabupaten/kota, dimana diasumsikan adanya keterkaitan pengaruh yang selalu tetap antara 1n(PDRB per kapita sektor pertanian, kehutanan, dan perikanan),
1n(PDRB per kapita sektor pertambangan dan penggalian), $\ln$ (PDRB per kapita sektor konstruksi), $\ln (\mathrm{PDRB}$ per kapita selain dari sektor pertanian, kehutanan, dan perikanan, sektor pertambangan dan penggalian, serta sektor konstruksi), $\ln (\mathrm{PMTB}), \mathrm{RLS}$, dan AHH pada setiap kabupaten/kota terhadap tingkat kemiskinannya.

Tabel 3 menunjukkan hasil estimasi faktorfaktor yang memengaruhi tingkat kemiskinan di Pulau Papua menggunakan fixed effect model (FEM) dengan metode within. Melalui angka $R$ squared sebesar 0.600 dapat dinyatakan bahwa 60 persen variasi nilai tingkat kemiskinan di Pulau Papua disebabkan oleh variasi variabelvariabel bebasnya, sedangkan sisanya sebesar 40 persen dipengaruhi faktor-faktor lain yang tidak disertakan dalam model. Oleh karena nilai $R$ squared lebih besar dari 0.50, dapat dikatakan model sudah cukup baik.

Hasil uji simultan dinyatakan dalam p-value dari $F$-statistic yang bernilai $2.22 \times 10^{-16}$. Dengan menenentukan taraf signifikan sebesar 1 persen, maka nilai $p$-value dari $F$-statistic lebih kecil dibandingkan taraf signifikan tersebut. Hal ini berarti bahwa variabel-variabel bebas dalam model secara simultan signifikan memengaruhi tingkat kemiskinan.

Tabel 3. Hasil estimasi regresi panel Fixed Effect Model

\begin{tabular}{ccccc}
\hline Variabel & Koefisien & Standart error & t-statistik & Probabilitas \\
\hline$X_{1}$ & 2.832 & 2.854 & 0.992 & 0.322 \\
$X_{2}$ & -5.179 & 1.443 & -3.590 & $0.000 * * *$ \\
$X_{3}$ & -5.040 & 1.735 & -2.905 & $0.004 * * *$ \\
$X_{4}$ & -2.598 & 3.036 & -0.856 & 0.393 \\
$X_{5}$ & 0.336 & 1.443 & 0.233 & 0.816 \\
$X_{6}$ & -2.136 & 0.517 & -4.132 & $0.000 * * *$ \\
$X_{7}$ & 0.116 & 0.481 & 0.242 & 0.809 \\
\hline -squared $\left(R^{2}\right)$ & & $:$ & 0.600 & \\
$F$-statistic & & 49.972 & dengan $p$-value $: 2.22 \times 10^{-16}$ \\
\hline
\end{tabular}

Keterangan : *** signifikan pada taraf nyata 1 persen

Pada hasil estimasi model FEM dalam Tabel 3 , terdapat 3 variabel yang signifikan dengan taraf 1 persen berpengaruh negatif terhadap tingkat kemiskinan di Pulau Papua, yaitu $X_{2}$ [ln(PDRB per kapita sektor pertambangan dan penggalian)], $X_{3}[\ln (\mathrm{PDRB}$ per kapita sektor konstruksi)], dan $X_{6}$ [RLS].

Nilai koefisien $X_{2}$ sebesar -5.179 , artinya setiap kenaikan 1 persen PDRB ADHK per kapita sektor pertambangan dan penggalian akan menurunkan tingkat kemiskinan sebesar 0.05179 persen poin dimana variabel bebas lain bernilai 
tetap. Koefisien $X_{3}$ sebesar -5.040 memiliki arti bahwa apabila nilai PDRB ADHK per kapita sektor konstruksi meningkat 1 persen, tingkat kemiskinan turun sebesar 0.0504 persen poin dimana variabel bebas lain bernilai tetap.

Tabel 4. Distribusi PDRB ADHK menurut Lapangan Usaha di Provinsi Papua dan Provinsi Papua Barat, 2011-2017 (persen)

\begin{tabular}{|c|c|c|c|c|c|c|c|}
\hline Lapangan Usaha & 2011 & 2012 & 2013 & 2014 & 2015 & 2016 & 2017 \\
\hline \multicolumn{8}{|l|}{ Provinsi Papua } \\
\hline A. Pertanian, Kehutanan, dan Perikanan & 11.44 & 12.15 & 12.88 & 13.61 & 14.32 & 14.57 & 15.15 \\
\hline B. Pertambangan dan Penggalian & 47.15 & 44.12 & 48.09 & 46.74 & 49.88 & 56.42 & 58.62 \\
\hline C. Industri Pengolahan & 2.08 & 2.12 & 2.17 & 2.36 & 2.45 & 2.56 & 2.72 \\
\hline D. Pengadaan Listrik dan Gas & 0.03 & 0.03 & 0.04 & 0.04 & 0.04 & 0.04 & 0.05 \\
\hline $\begin{array}{l}\text { E. Pengadaan Air, Pengelolaan Sampah, } \\
\text { Limbah dan Daur Ulang }\end{array}$ & 0.06 & 0.06 & 0.06 & 0.07 & 0.07 & 0.07 & 0.07 \\
\hline F. Konstruksi & 8.72 & 9.94 & 11.12 & 12.07 & 13.36 & 14.54 & 15.29 \\
\hline $\begin{array}{l}\text { G. Perdagangan Besar dan Eceran; Reparasi } \\
\text { Mobil dan Sepeda Motor }\end{array}$ & 7.09 & 7.79 & 8.51 & 9.14 & 9.88 & 10.56 & 11.22 \\
\hline H. Transportasi dan Pergudangan & 3.64 & 3.96 & 4.28 & 4.74 & 5.19 & 5.61 & 5.95 \\
\hline I. Penyediaan Akomodasi dan Makan Minum & 0.57 & 0.62 & 0.69 & 0.78 & 0.84 & 0.89 & 0.95 \\
\hline J. Informasi dan Komunikasi & 3.24 & 3.57 & 4.03 & 4.29 & 4.52 & 4.67 & 5 \\
\hline K. Jasa Keuangan dan Asuransi & 1.33 & 1.43 & 1.63 & 1.75 & 1.79 & 1.9 & 1.95 \\
\hline L. Real Estate & 2.09 & 2.3 & 2.56 & 2.77 & 2.93 & 3.14 & 3.31 \\
\hline M,N. Jasa Perusahaan & 1.09 & 1.16 & 1.23 & 1.34 & 1.4 & 1.48 & 1.56 \\
\hline $\begin{array}{l}\text { O. Administrasi Pemerintahan, Pertahanan } \\
\text { dan Jaminan Sosial Wajib }\end{array}$ & 7.4 & 8.02 & 8.24 & 9.47 & 10.5 & 11.51 & 12.01 \\
\hline P. Jasa Pendidikan & 1.83 & 2.01 & 2.2 & 2.37 & 2.54 & 2.74 & 2.89 \\
\hline Q. Jasa Kesehatan dan Kegiatan Sosial & 1.32 & 1.44 & 1.57 & 1.72 & 1.86 & 2.02 & 2.12 \\
\hline $\mathrm{R}, \mathrm{S}, \mathrm{T}, \mathrm{U}$. Jasa lainnya & 0.92 & 1 & 1.11 & 1.2 & 1.29 & 1.37 & 1.45 \\
\hline \multicolumn{8}{|l|}{ Provinsi Papua Barat } \\
\hline A. Pertanian, Kehutanan, dan Perikanan & 4.32 & 4.51 & 4.8 & 5.04 & 5.17 & 5.28 & 5.55 \\
\hline B. Pertambangan dan Penggalian & 10.6 & 10.17 & 10.29 & 10.38 & 10.51 & 10.59 & 10.43 \\
\hline C. Industri Pengolahan & 13.29 & 13.67 & 14.83 & 15.41 & 15.74 & 16.26 & 16.7 \\
\hline D. Pengadaan Listrik dan Gas & 0.01 & 0.02 & 0.02 & 0.02 & 0.02 & 0.02 & 0.02 \\
\hline $\begin{array}{l}\text { E. Pengadaan Air, Pengelolaan Sampah, } \\
\text { Limbah dan Daur Ulang }\end{array}$ & 0.05 & 0.05 & 0.05 & 0.05 & 0.06 & 0.06 & 0.06 \\
\hline F. Konstruksi & 3.5 & 3.96 & 4.58 & 5.15 & 5.65 & 6.2 & 6.79 \\
\hline $\begin{array}{l}\text { G. Perdagangan Besar dan Eceran; Reparasi } \\
\text { Mobil dan Sepeda Motor }\end{array}$ & 2.2 & 2.32 & 2.49 & 2.7 & 2.88 & 3.14 & 3.4 \\
\hline H. Transportasi dan Pergudangan & 0.74 & 0.84 & 0.95 & 1.07 & 1.16 & 1.25 & 1.36 \\
\hline I. Penyediaan Akomodasi dan Makan Minum & 0.2 & 0.21 & 0.22 & 0.23 & 0.25 & 0.27 & 0.29 \\
\hline J. Informasi dan Komunikasi & 0.55 & 0.65 & 0.71 & 0.79 & 0.85 & 0.93 & 1 \\
\hline K. Jasa Keuangan dan Asuransi & 0.4 & 0.47 & 0.58 & 0.64 & 0.7 & 0.72 & 0.74 \\
\hline L. Real Estate & 0.38 & 0.43 & 0.46 & 0.5 & 0.53 & 0.58 & 0.63 \\
\hline M,N. Jasa Perusahaan & 0.04 & 0.04 & 0.05 & 0.05 & 0.05 & 0.06 & 0.06 \\
\hline $\begin{array}{l}\text { O. Administrasi Pemerintahan, Pertahanan } \\
\text { dan Jaminan Sosial Wajib }\end{array}$ & 2.83 & 3.19 & 3.49 & 3.78 & 4.09 & 4.43 & 4.69 \\
\hline P. Jasa Pendidikan & 0.88 & 0.92 & 1.02 & 1.12 & 1.2 & 1.28 & 1.38 \\
\hline Q. Jasa Kesehatan dan Kegiatan Sosial & 0.3 & 0.32 & 0.33 & 0.34 & 0.37 & 0.39 & 0.42 \\
\hline R,S,T,U. Jasa lainnya & 0.1 & 0.1 & 0.11 & 0.12 & 0.13 & 0.14 & 0.15 \\
\hline
\end{tabular}

Sumber : BPS (2018d, 2018e), diolah 
Hasil penelitian yang menunjukkan bahwa peningkatan PDRB per kapita sektor pertambangan dan penggalian dan peningkatan PDRB per kapita sektor konstruksi dapat memengaruhi penurunan tingkat kemiskinan ini sejalan dengan hasil penelitian Murohman et al (2016) dan Ratri (2011). Peningkatan produksi dalam sektor pertambangan dan penggalian serta sektor konstruksi di Pulau Papua dapat meningkatkan pendapatan rumah tangga sehingga lebih berpeluang mengurangi kemiskinan.

Koefisien $X_{6}$ bernilai -2.136 memiliki arti bahwa peningkatan Rata-rata Lama Sekolah sebesar 1 tahun berpengaruh pada penurunan tingkat kemiskinan sebesar 2.136 persen poin dimana variabel bebas lain bernilai tetap. Variabel RLS merupakan variabel yang pengaruhnya terbesar di antara ketiga variabel yang berpengaruh dari hasil studi ini. RLS merupakan representasi dari tingkat pendidikan. Semakin besar nilai RLS sama artinya semakin tinggi pendidikan seseorang. Semakin tinggi pendidikan seseorang, maka semakin besar peluang untuk memeroleh pekerjaan yang pada akhirnya dapat meningkatkan kesejahteraan. Hasil penelitian tersebut sesuai dengan penelitian Bintang dan Woyanti (2018) yang menunjukkan bahwa pendidikan berpengaruh negatif terhadap tingkat kemiskinan.

Berdasarkan hasil estimasi model FEM dalam Tabel 3, variabel-variabel yang tidak signifikan berpengaruh terhadap tingkat kemiskinan adalah $X_{1} \quad[\ln ($ PDRB per kapita sektor pertanian, kehutanan, dan perikanan)], $X_{4}[\ln (\mathrm{PDRB}$ per kapita selain sektor pertanian, kehutanan, dan perikanan, sektor pertambangan dan penggalian, serta sektor konstruksi)], $X_{5}$ [ln(PMTB)], dan $X_{7}$ [AHH].

Ketidaksignifikan variabel PDRB per kapita serupa dengan penelitikan Adams (2003). Berdasarkan data yang digunakan, tidak signifikannya variabel PDRB per kapita sektor pertanian, kehutanan, dan perikanan dan variabel PDRB per kapita selain sektor pertanian, kehutanan, dan perikanan, sektor pertambangan dan penggalian, serta sektor konstruksi disebabkan tren data dari kedua variabel tersebut berfluktukasi, sedangkan tren data tingkat kemiskinan menurun.
Apabila dilihat dari nilai share PDRB ADHK menurut Lapangan Usaha per provinsi di Pulau Papua (Tabel 4), sektor pertanian, kehutanan, dan perikanan mengalami kemunduran secara proporsi. Sejak tahun 2011 hingga 2016, sektor pertanian, kehutanan, dan perikanan berada pada posisi ketiga di Provinsi Papua, namun berubah menjadi posisi keempat di tahun 2017. Perubahan nilai proporsi sektor pertanian, kehutanan, dan perikanan juga terjadi di Provinsi Papua Barat, dimana pada tahun 2011 hingga 2013 posisi sektor ekonomi tersebut berada pada urutan ketiga, namun pada tahun 2014 hingga 2017 menurun di posisi keempat.

Variabel PMTB atau investasi fisik dalam studi ini tidak signifikan memengaruhi tingkat kemiskinan di Pulau Papua. Menurut Murohman (2014) kebijakan alokasi investasi pemerintah daerah kurang efektif dalam mengentaskan kemiskinan karena alokasi investasi belum berbasis kemiskinan. Investasi perlu dialokasikan pada sektor ekonomi yang dapat memberikan efek menurunnya kemiskinan.

Selain PDRB dan PMTB, variabel AHH atau kesehatan juga tidak signifikan memengaruhi tingkat kemiskinan. Ketidaksignifikanan variabel AHH dapat disebabkan oleh sifat data AHH yang fluktuatif sepanjang tahun 2011 hingga 2017 pada masing-masing kabupaten/kota di Pulau Papua, sementara data tingkat kemiskinan memiliki tren menurun dalam periode yang sama. Ada kalanya saat tingkat kemiskinan kabupaten/kota mengalami penurunan, beberapa kabupaten/kota mengalami peningkatan nilai $\mathrm{AHH}$, sementara yang lain mengalami penurunan nilai $\mathrm{AHH}$.

\section{KESIMPULAN}

Berdasarkan seluruh pengujian empiris yang telah dilakukan, dapat diambil kesimpulan bahwa faktor-faktor yang memengaruhi tingkat kemiskinan di Pulau Papua adalah PDRB per kapita sektor pertambangan dan penggalian, PDRB per kapita sektor konstruksi, serta pendidikan. Ketiga hal tersebut berpengaruh signifikan pada penurunan tingkat kemiskinan.

Kebijakan pengembangan sektor ekonomi pertambangan dan penggalian oleh pemerintah daerah sebaiknya berpihak pada penduduk miskin. Pengembangan sektor konstruksi harus menganut program padat karya yang 
mempekerjakan penduduk Pulau Papua sehingga dapat memperluas lapangan pekerjaan guna meningkatkan kesejahteraan masyarakat. Rendahnya kualitas pendidikan di Pulau Papua umumnya disebabkan karena masih minimnya akses, sarana, dan prasarana pendidikan serta masih rendahnya kuantitas maupun kualitas pendidik. Oleh karena itu, pemerintah daerah perlu membangun akses, sarana, dan prasarana pendidikan, serta menambah tenaga pendidik berkualitas, khususnya derah terpencil.

\section{DAFTAR PUSTAKA}

Adams Jr R. 2004. Economic growth, inequality and poverty: estimating the growth elasticity of poverty. World Development. 32(12):1989-2014.

Baltagi BH. 2005. Econometrics Analysis of Panel Data. $3^{\text {rd }}$ ed. England: J Wiley.

Bintang ABM, Woyanti. 2018. Pengaruh PDRB, pendidikan, kesehatan, dan pengangguran terhadap tingkat kemiskinan di Jawa Tengah (2011-2015). Media Ekonomi dan Manajemen. 33(1):20-28.

[BPS] Badan Pusat Statistik. 2017. Data dan Informasi Kemiskinan Kabupaten/Kota. Jakarta: BPS.

[BPS] Badan Pusat Statistik. 2018a. Kemiskinan dan Ketimpangan. [Internet]. [diunduh 2018 September 11]. Tersedia pada: https://papuabarat.bps.go.id/subject/23/ke miskinan.html\#subjekViewTab3.

[BPS] Badan Pusat Statistik. 2018b. Kemiskinan dan Ketimpangan. [Internet]. [diunduh 2018 September 11]. Tersedia pada: https://papua.bps.go.id/subject/23/kemiskin an-dan-ketimpangan.html\#subjekView Tab3.

[BPS] Badan Pusat Statistik. 2018c. Kemiskinan dan Ketimpangan. [Internet]. [diunduh 2018 September 11]. Tersedia pada: https://www.bps.go.id/subject/23/kemiskin an-dan-ketimpangan.html\#subjek ViewTab3.

[BPS] Badan Pusat Statistik. 2018d. PDRB (Lapangan Usaha). [Internet]. [diunduh 2018 September 11]. Tersedia pada: https://papuabarat.bps.go.id/subject/52/pro duk-domestik-regional-bruto--lapanganusaha-.html\#subjekViewTab3.
[BPS] Badan Pusat Statistik. 2018e. PDRB (Lapangan Usaha). [Internet]. [diunduh 2018 September 11]. Tersedia pada: https://papua.bps.go. id/subject/154/pdrb-lapangan-usaha-.html\#subjekViewTab3.

[BPS] Badan Pusat Statistik. 2018f. PDRB (Pengeluaran). [Internet]. [diunduh 2018 September 11]. Tersedia pada: https://papua.bps.go.id/subject/11/pdrb-pengeluaran-.html\#subjekViewTab3.

[BPS] Badan Pusat Statistik. 2018g. PDRB (Pengeluaran). [Internet]. [diunduh 2018 September 11]. Tersedia pada: https://papuabarat.bps.go.id/subject/52/pro duk-domestik-regional-bruto-pengeluaran.html\#subjekViewTab3.

Jhingan ML. 2016. Ekonomi Pembangunan dan Perencanaan. Guritno D, penerjemah; Rajawali, editor. Jakarta (ID): PT Rajagrafindo Persada Press. Terjemahan dari: The Economics of Development and Planning. Ed ke-1.

[KEMENKEU] Kementerian Keuangan. 2019. Publikasi [internet]. [diunduh 16 Januari 2019]. Tersedia dari: https://www. kemenkeu.go.id/publikasi/laporan/ laporan-keuangan-pemerintah-pusat.

Murohman. 2014. Analisis dampak perubahan alokasi investasi pemerintah daerah terhadap pengentasan kemiskinan di Kalimantan Barat [tesis]. Bogor (ID): Institut Pertanian Bogor.

Murohman, Hutagaol MP, Asmara A. 2016. Pengembangan sektor ekonomi dan pengentasan kemiskinan di Kalimantan Barat. Jurnal Ekonomi dan Kebijakan Pembangunan. 5(1):45-62.

Quy NH. 2016. Relationship between economic growth, unemployment and poverty: analysis at provincial level in Vietnam. International Journal of Economics and Finance. 8(12):113-119.

Ratri WAM. 2011. Dampak penerimaan dan pengeluaran pemerintah daerah terhadap kinerja ekonomi dan kemiskinan di Indonesia [tesis]. Bogor (ID): Institut Pertanian Bogor

Todaro MP, Smith SC. 2006. Pembangunan Ekonomi. Jilid 1. Munandar H, Puji AL, penerjemah; Barnadi D, Saat S, Hardani 
W, editor. Jakarta (ID): Erlangga. Usman. 2006. Dampak desentralisasi fiskal Terjemahan dari: Economic Development. Ed ke-9. terhadap distribusi pendapatan dan tingkat kemiskinan [tesis]. Bogor (ID): Institut Pertanian Bogor. 